УДК 373.3.011.3-051:159.9.019.4-021.388(045)

DOI:

Олена Андрющенко, старший викладач кафедри початкової освіти Комунальний заклад “Запорізький обласний інститут післядипломноӥ педагогічної освіти” Запорізької обласної ради

\title{
РЕФЛЕКСИВНІ ВМІННЯ ВЧИТЕЛЯ ПОЧАТКОВИХ КЛАСІВ: СУТНІСТЬ I ХАРАКТЕРИСТИКА
}

У статті розкрито актуальність проблеми розвитку рефлексивних умінь учителів початкової школи. На основі аналізу психолого-педагогічної літератури уточнено зміст поняття “рефлексивні вміння педагога". Схарактеризовано та узагальнено наукові погляди щьодо визначення сутності поняття "рефлексивні вміння педагога" з позииії діяльнісного, системомиследіяльнісного, компетентнісного, аксіологічного підходів. Визначено зміст та подано характеристику видів рефлексивних умінь учителя початкових класів. Акиентовано увагу на необхідності формування рефлексивних умінь учителів початкових класів у системі післядипломної педагогічної освіти.

Ключові слова: рефлексія; рефлексивні вміння педагога; рефлексивні вміння вчителя початкових класів; післядипломна педагогічна освіта.

Табл. 2. Лім. 11.

Olena Andryushchenko, Senior Lecturer of the Primary Education Department Municipal Institution "Zaporizhzhya Regional Institute of Postgraduate Pedagogical Education" Zaporizhzhya Regional Council

\section{THE REFLECTIVE SKILLS OFTEACHER OF PRIMARY SCHOOL: ESSENCE AND CHARACTERISTICS}

The article reveals the urgency of the problem of development of reflexive skills of the primary school teachers. It is noted that according to the new professional standard "a Teacher of primary schools of general secondary education" for the first time a list of labor functions is presented, among which there is a reflection.

On the basis of the analysis of scientific sources the content of the concept "reflexive skills of the teacher" is clarified. It is found out that in the psychological and pedagogical literature this phenomenon is investigated from the standpoint of activity, competence, systematic, axiological approaches; in psychological and content aspects.

Different views on the definition of the essence of the concept "the teacher's reflexive skills" are illuminated, which are considered as: 1) difficult structured professional-personal formation of a teacher, for the analysis of the inner world, individual properties, the teacher's own activities; 2) the ability of the individual to adjust the existing perceptions of himself as a subject of educational and professional activities; 3) the ways of performing reflexive activity; 4) a system of conscious actions and operations aimed at understanding, comprehension and assessment by the subject of his activity, his own "I"; 5) the special pedagogical skills of the teacher for reflexive analysis of pedagogical activity; 6) the special professional skills that help the teacher to analyze, record and evaluate the results of their activities and activities of pupils; 7) the teacher's intellectual skills, influencing the formation of structures of arbitrary intellectual control.

The actual definition of the concept "reflexive skills of the primary school teacher" is proposed. The types of reflexive skills of the primary school teacher (intellectual, personal, activity and communicative) are represented and described. The prospects of further searches in the research of the mentioned concept are determined.

Keywords: reflection; reflexive skills of the teacher; reflexive skills of the teacher of primary school; postgraduate pedagogical education.

П остановка проблеми. Наближення України до європейських стандартів в економічному та культурному просторі, необхідність узгодження освітніх послуг і ринку праці зумовило реформування вітчизняної освітньої галузі, яке з 2018 року розпочалося в початковій школі. Упровадження ідей Нової української школи передбачає зміни в концептуальних підходах до навчання, в змісті та організації освітнього процесу, і головне - визначає потребу в педагогах, які володіють фаховими знаннями та вміннями, способами аналізу власної педагогічної діяльності з метою її вдосконалення відповідно до нових викликів суспільства й усвідомлюють необхідність постійного професійного саморозвитку. 3 огляду на це, пріоритетними завданнями закладів вищої та професійної педагогічної освіти, на нашу думку, $є$ 
розвиток рефлексії та рефлексивних умінь учителів початкової школи.

Зауважимо, що вперше в 2018 році було затверджено професійний стандарт "Вчитель початкових класів закладу загальної середньої освіти”, в якому визначено професійні компетентності, знання, уміння та навички, якими повинен володіти вчитель початкових класів. У професійному стандарті подано перелік трудових функцій педагога, однією з яких є “Рефлексія та професійний саморозвиток”. Цей нормативноправовий документ декларує необхідність розвитку рефлексії та рефлексивних умінь учителів початкової школи на всіх етапах неперервної освіти [8].

Аналіз основних досліджень і публікацій. Варто зазначити, що в різні часи науковці досліджували різноманітні аспекти феномена “рефлексивні вміння", визначаючи його як системоутворювальний чинник розвитку професійної діяльності вчителя, операціональний компонент рефлексивної компетентності (М.Н. Аверіна, О.В. Савченко, К.М. Татаурова та ін.), складник професійної компетентності педагога (I.А. Зимня, I.А. Зязюн, С.I. Вострокнутов, Н.В. Кузьміна, А.К. Маркова, Л.М. Мітіна, А.О. Реан, В.О. Сластьонін, І.Ф. Ісаєв та ін.), структурний елемент професійної педагогічної рефлексії майбутніх учителів початкової школи (М.М. Марусинець та ін.). У фокусі дослідників була проблема формування рефлексивних умінь студентів в освітньому процесі закладу вищої освіти (Т.П. Айсувакова, О.І. Герасимова, Т.В. Питинак, М.Ю. Прокоф’єва, С.О. Синельников, Т.Ф. Ушева та ін.), студентів - майбутніх учителів початкової школи (О.В. Алексєєва, О.С. Березюк, А. П. Лозенко та ін.), педагогів у системі педагогічної освіти, зокрема в процесі підвищення кваліфікації (М.Н. Аверіна, О.С. Сазонова та ін.). Досліджувалася й рефлексивна компетентність як умова розвитку професійної самосвідомості вчителя початкової школи в системі післядипломної освіти (В.В. Примакова), iї формування в майбутніх учителів початкових класів (Ю.О. Бабаян, К.Ф. Нор та ін.).

Однак, питання розвитку рефлексивних умінь учителів початкових класів у системі післядипломної освіти ще не знайшло свого відображення в теорії та практиці.

Отже, метою статті $\epsilon$ визначення сутності та характеристика видів рефлексивних умінь учителя початкових класів.

Виклад основного матеріалу. Перш за все, узагальнимо наукові підходи щодо визначення сутності поняття “рефлексивні вміння педагога" для виокремлення таких умінь у вчителя початкової школи.

Психологічний аспект феномену “рефлексивні вміння педагога" представлено у дослідженнях O.I. Герасимової. Науковець тлумачить їх сутність як складноструктуроване особистісне утворення, синтез усвідомлених дій, самоставлення, що втілюється в здатності особистості об'єктивно аналізувати свій внутрішній світ, індивідуальні властивості, діяльність, поведінку в різних ситуаціях $[4,44]$. У свою чергу, А.П. Лозенко означений феномен тлумачить як багатомірні комплексні психічні утворення індивіда, представлені системою знань і способів для здійснення різних видів рефлексії $[6,10] .3$ одного боку, рефлексивно-перцептивні вміння педагога в контексті питання продуктивності педагогічної діяльності, на думку А.О. Реана, утворюють органічний комплекс самопізнання індивідуально-психологічних особливостей, оцінювання свого психічного стану, здійснення різнобічного сприйняття й адекватного пізнання особистості учнів [9, 79]. 3 іншого боку, здійснення рефлексивно-перцептивного аналізу діяльності на основі відповідних здібностей і вмінь $\epsilon$ важливим чинником результативності педагогічної діяльності.

У роботах Ю.І. Семенова, Н.А. Тарасюк та ін. рефлексивні вміння розглядаються як здатність до регулювання наявних уявлень про себе як суб'єкта навчально-професійної діяльності, формування уявлень щодо прогнозування та планування власної діяльності, а також з'ясування та аналіз думок інших людей з означених питань $[10,160]$.

Діяльнісний підхід щодо визначення змісту поняття "рефлексивні вміння педагога" подано в доробках Л.С. Андрюшиної, М.Л. Лопарьової, Т.Ф. Ушевої та ін. Так, Т.Ф. Ушева означений феномен характеризує як засвоєні особистістю способи виконання рефлексивної діяльності на основі знань про сутність, засоби та способи здійснення рефлексії над власною діяльністю $[11,28]$.

Схожий підхід знаходимо в С.П. Білоконного, який рефлексивні вміння розглядає як загальнопрофесійні вміння, що допомагають учителю аналізувати, обліковувати й оцінювати результати власної діяльності та діяльності учнів 3 метою підвищення ефективності освітнього процесу $[3,16]$. У майбутніх педагогів означені вміння формуються в процесі рефлексивної діяльності під час проведення педагогічної практики.

З позиції компетентнісного підходу рефлексивні вміння досліджуються в наукових доробках 
І.Ф. Ісаєва, Т.В. Леонтьєвої, А.С. Роботової, В.О. Сластьоніна, І.Г. Шапошнікової та ін. Досягнення вчителем високих показників у професії неможливе без ретельного самоаналізу діяльності, що забезпечується сформованими рефлексивними вміннями. Саме тому, В.О. Сластьонін, крім загальнопрофесійних умінь педагога (аналітичних, прогностичних, проективних, організаційних і комунікативних) виокремлює

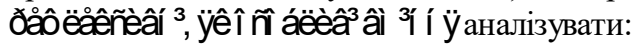

- правильність постановки цілей і завдань педагогічної діяльності;

- адекватність вирішення професійних завдань згідно з існуючими умовами;

- проектування змісту діяльності учнів відповідно до поставлених завдань;

- використання ефективних методів і засобів педагогічної діяльності;

- застосування організаційних форм відповідно до вікових особливостей учнів, рівня їх розвитку, змісту освіти тощо;

- причини успіхів і труднощів у ході реалізації освітнього процесу;

- досвід власної педагогічної діяльності відповідно до критеріїв та рекомендацій, запропонованими сучасною наукою $[7,47]$.

Змістовий аспект у визначенні рефлексивних умінь як особливої групи педагогічних умінь простежується у дослідженнях Т.П. Айсувакової, А.К. Маркової та ін. Означені вміння характеризують рівень рефлексивності мислення особистості, що виявляється в здатності до регуляції уявлень про себе як суб'єкта діяльності, результатів діяльності, способах і засобах іiі вдосконалення [1, 35].

Одними 3 найважливіших інтелектуальних умінь, що впливають на сформованість структур довільного інтелектуального контролю i, як наслідок, на інтелектуальний розвиток особистості в цілому, рефлексивні вміння вважають C I. Афанасьєва, А.І. Бежанова, Л.І. Дімент та ін. [2].
Як групу вмінь, що забезпечують рефлексивно-аксіологічний компонент креативної діяльності фахівця з позиції аксіологічного підходу, розглядає рефлексивні вміння М.М. Демидко. Варто зазначити, що до кожного компонента в структурі діяльності автор визначає відповідні рефлексивні вміння, а саме:

- оцінювати, аналізувати та коригувати мету згідно з вимогами діяльності (визначення мети діяльності);

- визначати логічні можливості виконання діяльності, готовність до перегляду власних дій (вибір способів діяльності);

- прогнозувати кінцевий результат; оцінювати ефективність своїх дій, брати відповідальність за власну діяльність (результат діяльності) [5, 12].

Цілком слушно на грунті аналізу теоретичної літератури та практичного досвіду вчителів С.П. Білоконний робить висновок про те, що структура досліджуваних умінь обумовлена логічною послідовністю основних етапів організації рефлексивної діяльності (мотиваційний, рефлексивно-діяльнісний, рефлексивно-оцінний), кожному з яких відповідає комплекс умінь $[3,16]$ (висвітлено в таблиці 1):

Спираючись на наукові погляди Г.П. Щедровицького стосовно форм здійснення рефлексії - колективної (комунікативної, кооперативної) та індивідуальної (інтелектуальної, особистісної), Т.Ф. Ушева конкретизує рефлексивні вміння стосовно кожного аспекту рефлексії, а саме:

- інтелектуальні - вміння визначати підстави діяльності, оцінювати власну позицію та прогнозувати подальший перебіг дій, уміння рефлексивно оцінювати правильність обраного плану;

- особистісні - вміння аналізувати й адекватно сприймати себе, визначати й аналізувати причини власної поведінки, а також їі результативні параметри та допущені помилки;

Таблиця 1.

Комплекс рефлексивних умінь (за С.П. Білоконним)

\begin{tabular}{|c|l|}
\hline \multicolumn{1}{|c|}{$\begin{array}{c}\text { Етапи рефлексивної } \\
\text { діяльності }\end{array}$} & \multicolumn{1}{c|}{ Комплекс рефлексивних умінь } \\
\hline Мотиваційний & $\begin{array}{l}\text { активно включатися в пізнавальну діяльність; } \\
\text { самостійно набувати педагогічний досвід; }\end{array}$ \\
\hline \begin{tabular}{|l|l|} 
Рефлексивно- \\
діяльнісний
\end{tabular} & $\begin{array}{l}\text { здійснювати діагностику; } \\
\text { спостерігати та аналізувати діяльність колег й учнів; } \\
\text { моделювати навчально-виховної процес; } \\
\text { здійснювати самоаналіз; }\end{array}$ \\
\hline Рефлексивно-оцінний & $\begin{array}{l}\text { здійснювати взаємоперевірку і взаємооцінювання діяльності колег; } \\
\text { об’єктивне самооінювання власної діяльності }\end{array}$ \\
\hline
\end{tabular}


розуміти особистісні якості на сучасному етапі в порівнянні з минулим і прогнозувати перспективи розвитку;

- комунікативні - вміння “стати на місце іншого”, розуміти мотиви дій іншого суб'єкта в процесі взаємодії, аналізувати життєві ситуацій та враховувати дії інших у своїх поведінкових стратегіях;

- кооперативні - самовизначення в робочій ситуації, вміння здійснювати покрокову організацію діяльності, брати відповідальність за те, що відбувається в групі, співвідносити результати 3 метою діяльності [11, 28 - 29].

3 огляду на вищезазначене, констатуємо, що рефлексивні вміння педагога в психологопедагогічній літературі висвітлюються з позиції діяльнісного, компетентнісного, аксіологічного, системомиследіяльнісного підходів; у психологічному та змістовому аспектах. Феномен “рефлексивні вміння педагога" розглядають як: складноструктуроване професійно-особистісне утворення вчителя, здатність особистості, способи рефлексивної діяльності, комплекс усвідомлених дій та операцій; особливі педагогічні, загальнопрофесійні та інтелектуальні вміння педагога.

На підставі розглянутих підходів розуміємо, що сугність феномену “рефлексивні вміння педагога” тлумачиться в семантичній єдності понять “педагогічна рефлексія” та “уміння”. Отже, якщо педагогічна рефлексія це - процес аналізу вчителем особистісних думок, пов'язаних 3 професійно-педагогічноюдіяльністю(Ю.О. Приходько, В.І. Юрченко та ін.), а уміння - контрольовані свідомістю способи дій, які складаються 3 упорядкованого ряду операцій, що мають спільну мету (І.Я. Лернер), пропонуємо визначати рефлексивні вміння вчителя початкових класів як професійно-особистісне утворення, систему усвідомлених дій та операцій для здійснення вчителем об'єктивного аналізу особистісних і професійних якостей, власної педагогічної діяльності, комунікацій зі всіма учасниками освітнього процесу.

У контексті нашого дослідження характеристика рефлексивних умінь учителя початкових класів грунтується на положеннях системомиследіяльнісного (М.Г. Алексєєв, Г.П. Щедровицький, А.О. Тюков, та ін.), акмеологічного (Н.В. Бордовська, А.О. Реан та ін.) підходів, дослідженнях різних аспектів рефлексії (І.Н. Семенов, С.Ю. Степанов та ін.), з урахуванням того, що рефлексивні процеси $є$ включеними в регуляцію практично всіх сфер активності особистості, зокрема їі професійної діяльності (А.В. Карпов). Виходячи 3 цього, виокремлюємо за змістом: інтелектуальні, особистісні, діяльнісні та комунікативні рефлексивні вміння вчителя початкових класів (табл. 2).

Висновки. Професія вчителя, зокрема вчителя початкової школи є досить суперечливою, оскільки будується на постійному діалектичному поєднанні консерватизму, збереженні освітніх традицій з необхідними інноваціями. Загострення цих протиріч особливо відчувається на сучасному етапі реформування початкової освіти. Відповідно до цього, розвиток рефлексивних умінь учителів початкових класів стає актуальним завданням у системі професійної підготовки педагогів. Рефлексивні вміння вчителя початкових класів розглядаємо як універсальний інструмент суб'єктної реалізації педагога, компонент

Таблиця 2.

Характеристика видів рефлексивних умінь учителя початкових класів за змістом

\begin{tabular}{|c|c|c|}
\hline $\begin{array}{c}\text { Вид рефлексивних } \\
\text { умінь }\end{array}$ & $\begin{array}{c}\text { Сфера психологічної } \\
\text { реалізації }\end{array}$ & Рефлексивні вміння вчителя початкових класів \\
\hline Інтелектуальні & $\begin{array}{l}\text { когнітивна; } \\
\text { перцептивна }\end{array}$ & $\begin{array}{l}\text { Аналіз педагогом: } \\
\text { предметної ситуації та співвіднесення з нею власних дій; } \\
\text { логіки власної мисленнєвої діяльності в процесі } \\
\text { розв’язання педагогічних і життєвих ситуацій; } \\
\text { індивідуально-психологічних особливостей; } \\
\text { сприйняття та адекватного пізнання інших людей }\end{array}$ \\
\hline Особистісні & $\begin{array}{l}\text { особистісне Я; } \\
\text { професійне Я }\end{array}$ & 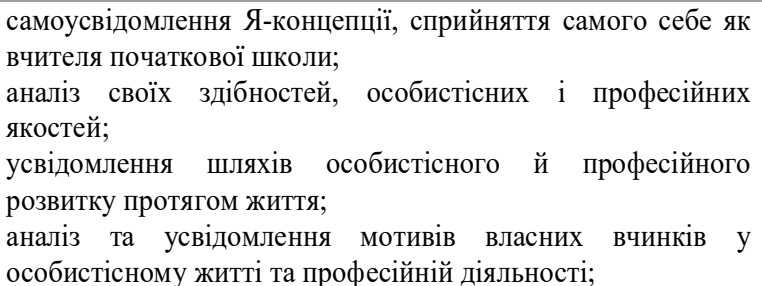 \\
\hline
\end{tabular}


Продовження таблиці 2.

\begin{tabular}{|c|c|c|}
\hline Діяльнісні & професійна діяльність & $\begin{array}{l}\text { аналіз мети діяльності (педагогічної діяльності), } \\
\text { усвідомлення їі трансформації в конкретні завдання; } \\
\text { аналіз вибору необхідних методів, засобів, форм реалізації } \\
\text { діяльності (педагогічної діяльності) відповідно до мети, } \\
\text { результату, існуючих умов, вікових та індивідуальних } \\
\text { особливостей молодших школярів тощо; } \\
\text { контроль і корекція (у разі необхідності) поточної } \\
\text { діяльності; } \\
\text { оцінювання успішності / неуспішності, результатів } \\
\text { виконаної діяльності з позиції їі ефективності; }\end{array}$ \\
\hline Комунікативні & $\begin{array}{c}\text { особистісна та } \\
\text { професійна комунікація }\end{array}$ & $\begin{array}{l}\text { аналіз: } \\
\text { міжособистісної взаємодії учасників освітнього процесу } \\
\text { (діти, батьки, колеги, адміністрація); } \\
\text { того, як тебе розуміють партнери по спілкуванню; } \\
\text { організації спільної діяльності в життєви і педагогічних } \\
\text { ситуаціях; } \\
\text { педагогічних технік спілкування щодо доцільного } \\
\text { використання їх в освітньому процесі початкової школи }\end{array}$ \\
\hline
\end{tabular}

саморегуляції особистості, дієвий механізм розвитку педагогічної діяльності, вагомий чинник, що забезпечує ії̈ успішність та вдосконалення.

Проведений аналіз не висвітлює всіх аспектів розглянутого питання. Перспективи подальших наукових пошуків полягають у визначенні шляхів розвитку рефлексивних умінь учителів початкових класів у системі післядипломної педагогічної освіти.

\section{ЛІТЕРАТУРА}

1. Айсувакова Т.П. Психологические условия развития рефлексивных учений студента будущего учителя: автореф. дис. на соискание уч. степени канд. псих. наук: спец. 19.00.07 "Педагогическая психология" / Т.П. Айсувакова. - Самара, 2008. - 23 с.

2. Афанасьева С. И. Формирование рефлексивных умений студентов в процессе обучения [Електронний pecypc] / С. И. Афанасьева, А. И. Бежанова, Л. И. Димент - Режим доступу до ресурсу: https:// cyberleninka.ru/article/v/formirovanie-refleksivnyhumeniy-studentov-v-protsesse-obucheniya.

3. Білоконний С.П. Формування рефлексивних умінь студентів педагогічних університетів у процесі педагогічної практики: автореф. на здобуття наук. ступеня канд. пед. наук: спец. 13.00.04 "Теорія і методика професійної освіти" / С.П. Білоконний. - Черкаси, 2011 - 23 с.

4. Герасимова О.І. Формування рефлексивних умінь студентів педагогічного університету в процесі навчання філологічних дисциплін: автореф. на здобуття наук. ступеня канд. пед. наук: спец. 13.00.09 “Теорія навчання"/ О.І. Герасимова. К., 2014. - 20 c.

5. Демидко М. Н. Формирование рефлексивных умений у обучающихся в средних специальных учебных заведениях: методические рекомендации / М.Н. Демидко. - Минск: РИПО, 2001. - 31 с.

6. Лозенко А.П. Формування рефлексивних умінь у майбутніх учителів початкової школи в процесі дидактичної підготовки: автореф. на здобуття наук. ступеня канд. пед. наук: спец. 13.00.09 "Теорія навчання" / А.П. Лозенко. - К., $2010-25$ c.

7. Педагогика: Учебное пособие для студентов педагогических учебных заведений / В.А. Сластенин, И.Ф. Исаев, А.И. Мищенко, Е.Н. Шиянов. - 3-е изд. - М.: Школа-Пресс, 2000. $-512 \mathrm{c}$.

8. Професійний стандарт “Вчитель початкових класів закладу загальної середньої освіти”. [Електронний ресурс] - Режим доступу до pecypcy: https://www.msp.gov.ua/files/News/ 20180815/20180815.pdf

9. Реан А. А. Рефлективно-перцептивный анализ деятельности педагога / А. А. Реан. // Вопросы психологии. - 1990. - №2. - С. 77-81.

10.Тарасюк Н. А. Развитие рефлексивных умений как основа профессиональной подготовки. / Н. А. Тарасюк, Ю. И. Семенова. // Высшее образование в России. - 2010. - №12. - С. 159162.

11. Ушева Т.Ф. Педагогические условия формирования рефлексивных умений студентов в учебном процессе вуза: дис. на соискание уч. степени канд. пед. наук: спец. 13.00.01 “Общая педагогика, история педагогики и образования” / Т.Ф. Ушева. - Иркутс, 2009. - 184 с.

\section{REFERENCES}

1. Aysuvakova, T. P. (2008). Psikhologicheskiye 
usloviya razvitiya refleksivnykh ucheniy studenta budushchego uchitelya [Psychological conditions for the development of student's reflective teachings the future teacher]. Candidate's thesis. Samara, 23 p. [in Russian].

2. Afanasyeva, S. I., Bezhanova, A. I. \& Diment, L. I. (2013). Formirovaniye refleksivnykh umeniy studentov $\mathrm{v}$ protsesse obucheniya [Formation of reflective skills of students in the learning process]. [Electronic resource]. Available at: https://cyberleni nka.ru/article/v/formirovanie-refleksivnyh-umeniystudentov-v-protsesse-obucheniya [in Russian].

3. Bilokonnyi, S. P. (2011). Formuvannia refleksyvnykh umin studentiv pedahohichnykh universytetiv u protsesi pedahohichnoi praktyky [Formation of reflexive abilities of students of pedagogical universities in the process of pedagogical practice]. Extended abstract of candidate's thesis. Cherkasy, 23 p. [in Ukrainian].

4. Herasymova, O. I. (2014). Formuvannia refleksyvnykh umin studentiv pedahohichnoho universytetu $\mathrm{v}$ protsesi navchannia filolohichnykh dystsyplin [Formation of reflexive abilities of students of the University of Pedagogy in the process of studying philological disciplines]. Extended abstract of candidate's thesis. Kyiv, 20 p. [in Ukrainian].

5. Demidko, M. N. (2001). Formirovanie refleksivnykh umeniy u obuchayushchikhsya $v$ srednikh spetsialnykh uchebnykh zavedeniyakh: metodicheskie rekomendatsii [The formation of reflective skills of students of secondary specialized educational institutions: guidelines]. Minsk: RIPO, 31p. [in Russian].

6. Lozenko, A. P. (2010). Formuvannia refleksyvnykh umin u maibutnikh uchyteliv pochatkovoi shkoly $\mathrm{v}$ protsesi dydaktychnoi pidhotovky [The formation of reflective skills of future teachers of primary school in the process of didactic training]. Extended abstract of candidate's thesis. Kyiv, 25p. [in Ukrainian].

7. Slastenin, V. A., Isayev, I. F., Mishchenko, A. I. \& Shiyanov, Ye. N. (2000). Pedagogika: Uchebnoye posobie dlya studentov pedagogicheskikh uchebnykh zavedeniy [Pedagogy: a manual for students of pedagogical educational institutions]. Moscow: School-Press, 512 p. [in Russian].

8. Profesiinyi standart "Vchytel pochatkovykh klasiv zakladu zahalnoi serednoi osvity" [Professional standard "Teacher of elementary schools of general secondary education"]. [Electronic resource]. Available at: https://www.msp.gov.ua/files/News/ 20180815/20180815.pdf [in Ukrainian].

9. Rean, A. A. (1990). Reflektivno-pertseptivnyy analiz deyatelnosti pedagoga [Reflective-perceptual analysis of the teacher]. Journal "Issues of Psychology”. Moscow, no. 2, pp. 77 - 81. [in Russian].

10. Tarasyuk, N. A. \& Semenova, Yu. I. (2010). Razvitie refleksivnykh umeniy kak osnova professionalnoy podgotovki [The development of reflective skills as the basis of training]. Scientific and pedagogical journal "Higher Education in Russia”, no.12, pp. 59-162. [in Russian].

11. Usheva, T. F. (2009). Pedagogicheskiye usloviya formirovaniya refleksivnykh umeniy studentov $\mathrm{v}$ uchebnom protsesse vuza [Pedagogical conditions of formation of reflexive skills of students in the educational process of the university]. Candidate's thesis. Irkutsk, 184 p. [in Russian].

Стаття надійшла до редакції 06.11.2018

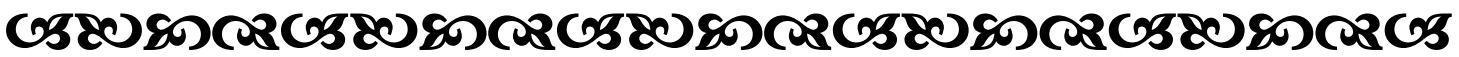

“Нехай він вірить в себе, i йому повірить весь світ".

$$
\begin{array}{r}
\text { Wиллер } \\
\text { німецьький поет, білособ }
\end{array}
$$

“Маленькі добрі справи, зроблені від великої любові, приносять радість і спокій".

Мати Tाереза

католищъка черниця, засновниия доброчиннихмісій

“У разі сумнівів чини так, як, соняшник- шуқай джерело світла і повертайся в його Бik”.

Бернар Вербер

браниузький прозаїк

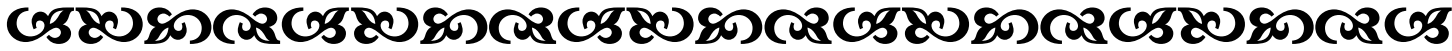

